
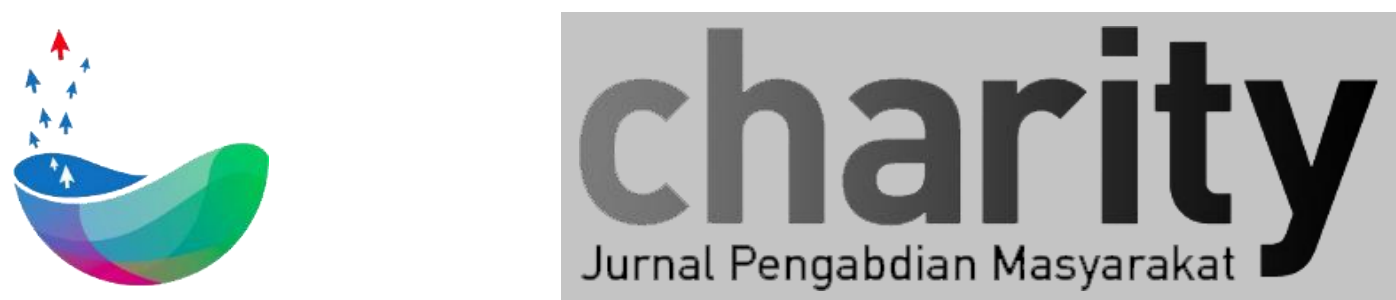

\title{
Sosialisasi Implementasi Prototype Portal Manajemen Sumber Daya High Performance Computing (HPC): Simulasi Dinamika Molekular
}

\author{
Heru Suhartanto ${ }^{1}$, Arry Yanuar $^{2}$, Ari Wibisono $^{3}$, Yohanes Gultom $^{4}$
}

Fakultas Ilmu Komputer, Universitas Indonesia

Fakultas Farmasi, Universitas Indonesia

Fakultas Ilmu Komputer, Universitas Indonesia

Fakultas Ilmu Komputer, Universitas Indonesia

*heru@cs.ui.ac.id, arry.yanuar@ui.ac.id, ari.w@cs.ui.ac.id, yohanes.gultom@alumni.ui.ac.id

\section{INFO ARTIKEL}

Diterima 12 Desember 2019

Direvisi 12 Juni 2020 Disetujui

27 Agustus 2020

Tersedia Online 28 Agustus 2020

\section{ABSTRAK}

Masalah pertama yang dihadapi terkait kegiatan ini adalah Penggunaan sumber daya High Performance Computing (HPC) membutuhkan fasilitas superkomputer yang sangat mahal, baik pengadaan maupun perawatannya Fasilitas HPC tersebut hanya dimiliki institusi tertentu yang memiliki sumber pendanaan cukup besar, termasuk di Indonesia. Hal ini menjadi suatu hambatan tersendiri, terutama untuk kasus penelitian yang menuntut sumber daya komputasi besar. Masalah kedua yakni para peneliti yang umumnya berasal dari berbagai macam disiplin ilmu pengetahuan sering tidak memiliki kemampuan tentang bagaimana menggunakan infrastruktur HPC tersebut. Salah satu alternatif solusi, yaitu dengan penggunaan layanan Cloud Infrastruktur-as-a-Service (IAAS), di mana layanan cloud tersebut menyediakan infrastruktur HPC. Sosialisasi pengenalan dan ujicoba prototype tersebut telah dilakukan kepada beberapa rekan dosen, peneliti dan mahasiswa di Universitas Padjajaran dan Institute Teknologi Bandung. Berdasarkan hasil kuesioner kegiatan sosialisasi ini, seluruh peserta merasa puas dengan kegiatan sosialisasi ini dan menganggap prototype tersebut dapat membantu

Korespondensi:

Heru Suhartanto, Fakultas Ilmu Komputer UI, Gedung A, ruang 1216, J1. Nugroho Notosusanto, Kampus UI,

Depok 16424, Jawa Barat

ORCID ID:

0000-0002-7659-6563: Heru Suhartanto

https://doi.org/xxx

Paper_reg_number xxx ( $)$ The Authors. Published by Directorate of Research and Community Service, Telkom University.

This is an open access article under the $\mathrm{xxx}$ license (https://creativecommons.org/licenses/xxx)

This is an open access article under the xxx license (https://creativecommons.org/licenses/xxx) 


\section{Pendahuluan}

Terdapat dua masalah yang hendak diatasi dalam kegiatan ini. Masalah pertama yakni perlunya portal manajemen Sumber Daya HPC untuk simulasi dinamika molekuler.Dunia penelitian sains dan teknologi kemudian melirik High Performance Computing (HPC) sebagai salah satu utilitas pemroses job dalam melakukan penelitian. Lingkungan komputasi HPC adalah sumber daya komputer berkinerja tinggi yang di dalamnya dilakukan eksekusi perintah untuk memproses job. HPC dipandang sebagai solusi akan kebutuhan komputasi berkecepatan tinggi (Resource Hungry Application) dalam berbagai bidang penelitian sains dan teknologi, seperti; material simulation (Jorissen et al., 2012), molecular dynamics simulation (Wibisono dan Suhartanto, 2012), earth observation data processing (Chen et. al., 2012) dan lain sebagainya. Seiring dengan itu, software aplikasi untuk penelitian sains pun saat ini mulai dirancang agar dapat berjalan dan memaksimalkan sumber daya HPC (Abdelbaky, et. al, 2012).

Seperti halnya penelitian dinamika molekular untuk keperluan penelusuran obat menggunakan aplikasi simulasi semacam Amber (Ambermd, 2015) dan Gromacs (Gromacs, 2015), Kedua aplikasi tersebut dirancang agar bisa berjalan di lingkungan komputasi parallel baik komputasi cluster multi-cpu maupun GPU. Dimana hasilnya menunjukkan peningkatan efisiensi waktu yang lebih baik dibandingkan jika dijalankan dengan cara konvensional sekuensial. Pemanfaatan HPC dalam simulasi dinamika molekular tersebut menunjukkan betapa HPC merupakan solusi dari eksperimen in silico dalam bidang penelitian kimiafarmasi, yang menawarkan peningkatan efisiensi waktu maupun penghematan biaya.

Eksperimen in silico merupakan model eksperimen modern yang memiliki arti "Dilakukan dalam komputer, atau melalui simulasi komputer" (Holl et. al., 2014). Eksperimen in silico tersebut merupakan alternatif dari dua model eksperimen sebelumnya, yakni in vivo (hingga 1970) dan in vitro (1970-1990). In vivo merupakan istilah untuk pendekatan eksperimen menggunakan hewan berbasis laboratorium. Sedangkan in vitro merupakan istilah untuk eksperimen di dalam gelas kaca menggunakan enzyme enhibition dan receptor binding. Pendekatan in silico tersebut dimaksudkan agar mempercepat waktu penelusuran serta mengurangi biaya laboratorium dan uji coba klinis. Pemanfaatan HPC untuk eksperimen in silico, akan membawa kekuatan komputasi besar dalam bidang penelitian farmasi, terutama terkait eksperimen simulasi dinamika molekular. Sehingga diharapkan akan mampu mempercepat proses penelusuran obat baru, yang selanjutnya akan berkontribusi kepada kesehatan manusia.

Penggunaan HPC membutuhkan fasilitas superkomputer yang sangat mahal, baik pengadaan maupun perawatannya. Sehingga fasilitas HPC tersebut hanya dimiliki institusi tertentu yang memiliki sumber pendanaan cukup besar. Terutama di Indonesia, mungkin hanya segelintir lembaga pendidikan dan penelitian yang mampu memilikinya. Hal ini mengakibatkan, pemanfaatan HPC untuk penelitian menjadi terbatas, karena sangat sedikit sekali aktivitas penelitian yang memiliki akses ke fasilitas.

HPC tertentu. Sehingga hal ini menjadi suatu hambatan tersendiri, terutama untuk kasus penelitian yang menuntut sumber daya komputasi besar.Mengatasi masalah tersebut muncul satu alternatif solusi, yaitu dengan penggunaan layanan komputasi cloud Infrastruktur-as-a-Service (IAAS), dimana layanan komputasi cloud tersebut menyediakan infrastruktur HPC. Layanan infrastruktur tersebut meliputi prosesor, memory, storage, jaringan internet, listrik serta perawatan. Saat ini banyak bermunculan vendor IAAS, seperti Amazon EC2 (Elastic Computing Cloud for Computing Service), S3 (Simple Storage Service), Microsoft Azure (PAAS), Google 
AppEngine, dan lainnya. Provider cloud IAAS tersebut menawarkan elasticity dan kemudahan scale-up, dimana kebutuhan akan infrastruktur tersebut bisa diperbesar sesuai dengan pertumbuhan kebutuhan sumber daya komputasi (Rajan et all, 2011). Dengan model pembiayaan pay-as-you-go, dimana customer hanya membayar sesuai dengan besar infrastruktur yang digunakan, IAAS dipandang sebagai solusi tepat akan kebutuhan infrastruktur HPC terutama terkait masalah biaya pengadaan, perawatan, serta skalabilitas.

Penelitian terdahulu mengusulkan model cloud computing yang meliputi lima kriteria, yakni: On-Demand self-service, Broad Network Access, Resource Pooling, Rapid elasticity, serta Measured Service (Wibisono and Suhartanto, 2012). Dalam penelitian tersebut dibangun antar muka berbasis web, yang digunakan untuk memfasilitasi penelitian simulasi dinamika molekular dalam lingkungan komputasi cluster.

Seiring berkembangnya infrastruktur lingkungan komputasi di laboratorium Architecture \& High-Performance Computing FASILKOM UI, muncul persoalan terkait integrasi lingkungan komputasi baru terhadap infrastruktur cloud computing yang sudah ada. Hal tersebut karena rancangan Software as a Service (SAAS) cloud computing terdahulu tidak memungkin penambahan lingkungan komputasi baru tanpa merombak kode program.

Masalah kedua yang hendak diatasi, terkait dengan kondisi aktifitas user bidang terkait termasuk mitra sosialisasi ini. Para peneliti yang umumnya berasal dari berbagai macam disiplin ilmu pengetahuan sering tidak memiliki kemampuan tentang bagaimana menggunakan infrastruktur HPC tersebut. Umumnya, pengguna HPC cloud akan diberikan beberapa server virtual, kemudian server virtual tersebut harus disiapkan secara mandiri sesuai kebutuhan aplikasinya. Setup tersebut berkaitan dengan instalasi Sistem operasi, midleware, aplikasi, serta beberapa konfigurasi yang tidak sederhana. (Rajan et all, 2011) Sehingga, peneliti tersebut harus bertambah pekerjaan dan waktu tambahan untuk mempelajari suatu kemampuan lain yang cukup rumit di luar esensi penelitian itu sendiri agar mampu menggunakan cloud IAAS tersebut. Sebagai user, mereka akan sangat sulit sekali untuk menyiapkan lingkungan komputasi HPC, dan menintegrasikan ke dalama system Cloud, melakukan eksperimen yang sama tetapi pada lingkungan HPC yang berbeda.

Masyarakat yang kami jadikan mitra adalah peneliti di Universitas Indonesia, ITB dan Universitas Padjadjaran. Para peneliti di mitra saat ingin melakukan eksperimen simulasi dengan perangkat lunak Amber, Gromacs dan Autdock, perlu menyiapkan lingkungan komputasi HPC seperti lingkungan Cluster dan GPU. Persiapan yang dilakukan antara lain memasang operating system, memasang perangkat lunak Amber, Gromacs dan Autodock. Dalam pemasangan ini, mereka dibantu oleh para peneliti dari Fakultas/Departmenet Ilmu Komputer/Teknologi Informasi. Jika lingkungan HPC yang berbeda akan dipakai untuk menghasilkan hasil eksperimen yang lebih baik, maka proses pemasangan yang rumit tersebut harus diulang. 
Keadaan lingkungan komputasi mitra sekarang dalam penggunaan Dinamika Molekular menggunakan computer CPU i7, memory 32 GB, Operating System Linux, memakai perangkat Amber versi 14, Gromacs versi 2018, Autodock versi 4.0 dan Autodock Vina. Target waktu produksi simulasi dinamika molekul yang dilakukan 50 ns. Realisasi waktu komputasi yang terpakai 72 jam (bergantung besar sistem yang disimulasi) GPU yang dipakai adalah GeForce GTX 1070. Targetnya atau harapan dengan memakai prototype CLOUD dari UI yakni dapat mempersingkat waktu perhitungan/simulasi sehingga dapat memfasilitasi perkembangan kegiatan penelitian di bidang komputasi.

\section{APLIKASI IPTEKS}

\subsection{Teori Dasar}

Mengatasi masalah pertama yakni keberadaan infrastruktur HPC yang mudah diakses tersebut, dalam penelitian sebelumnya pengusul telah pengembangan model SAAS-cloud dimana lingkungan komputasi HPC baru memungkinkan untuk diintegrasikan ke dalam infrastruktur cloud itu sendiri. Model SAAS-cloud yang diusulkan diharapkan mampu menangani adanya penambahan lingkungan komputasi baru, tanpa melakukan perombakan terhadap kode program serta dengan upaya yang seminimal mungkin. Di samping itu, desain model SAAS-cloud tersebut diharapkan memiliki fitur yang cukup untuk menangani kebutuhan user dalam penggunaan aplikasi simulasi dinamika molekular di atas lingkungan komputasi HPC. Mengadopsi model Cloud Computing Software-as-a-Service (SAAS), model tersebut kemudian diimplementasikan menjadi sebuah platform aplikasi berbasis web dengan nama CloudMD (Cloud for Molecular Dynamic). Platform CloudMD yang diusulkan diharapkan dapat menghilangkan effort pekerjaan ekstra dalam mempelajari mekanisme akses low-level HPC, sehingga menjadikan fokus kembali lagi kepada esensi penelitian.

Secara khusus, solusi berupa cloudbased HPC berbasis layanan Software-as-aService.Solusi tersebut diharapkan mampu melayani kebutuhan user akan sumber daya komputasi HPC. Solusi tersebut memiliki mekanisme akses yang lebih mudah dan dengan hasil yang tidak berbeda dibandingkan dengan mekanisme akses konvensional

Solusi tersebut mampu menangani adanya integrasi lingkungan komputasi baru, tanpa melakukan perubahan terhadap kode program. Prototype yang sudah dikembangkan, akan diujicoba dengan integrase infrastruktur lainnya di dalam maupun di luar UI.

Sementara untuk mengatasi masalah terkait masyarakat peneliti mitra UI, ITB dan UNPAD, Penulis merencanakan pelatihan bagi setiap mitra peneliti bagaimana membuat akun, mempunyai space, menyimpan data, melakukan eksperimen diberbagai lingkungan HPC, mengambil hasil eksperimen. Dari kegiatan ini maka diharapkan tercapai target program pengabdian masyarakat antara lain 
Terbentuknya para motivator (peneliti) yang memahami, mempunyai afeksi, dan terampil penggunaan prototype cloudBased-HPC dalam pemberdayaan masyarakat lokal

Tertransformasinya kesadaran, komitmen, kemauan, pengetahuan, keterampilan dan afeksi motivator dalam pemanfaatan prototype cloudBased-HPC terhadap para kolega peneliti dosen dan mahasiswa.

Meningkatkan kapasitas masyarakat/peneliti dalam melakukan simulasi molecular dinamis secara efisien.Nilai jawaban kuesioner yang telah dirancang menunjukkan kemudahan pemakaian prototype CloudBasedHPC dan lebih efisiennya proses eksperimen.

\subsection{Gambaran IPTEKS}

Pengembangan portal system cloud HPC untuk proses simulasi dinamika molekuler, telah dikembangkan prototype. Pertama kali oleh (Wibisono dan Suhartanto, 2012), dimana sumberdaya yang disediakan masih system komputasi Cluster, kemudian dilanjutkan oleh (Ratsanjani, 2016) dimana sumberdaya yang disediakan system komputasi Cluster dan GPU namun belum dilengkapi dengan mekanisme load-balance. Pengembangan terakhir dilakukan oleh (Kamah, 2017) dan sudah disajikan di pertemuan internasional (Kamah et. Al, 2018). Hasil terakhir ini yang akan digunakan dalam kegiatan ini. Beberapa penyesuaian dilakukan agar prototype dapat mengakses fasilitas HPC di luar kampus UI.

Berikut adalah rancangan arsitektur fisik portal secara keseluruhan serta dua pool yang digunakan untuk kegiatan di proposal ini:

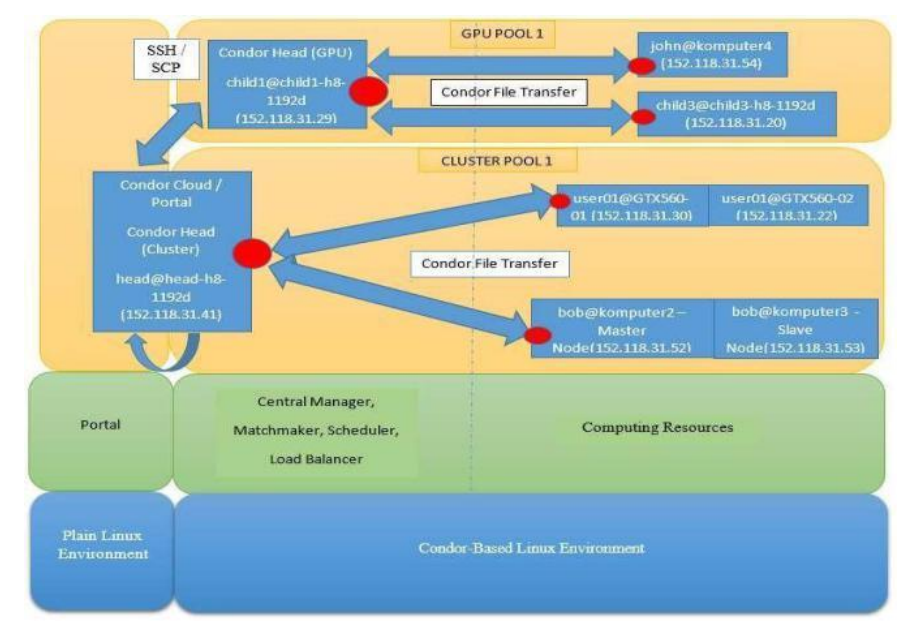

Penjelasan perihal arsitektur di atas, antara lain:

Pada bagian yang berwarna kuning krem, menunjukkan komputer-komputer yang diinstal (terdiri dari pool HPC resources dan portal-nya), yang mencantumkan juga username dan hostnamenya, serta alamat IP-nya. Pada kotak berwarna putih 
menunjukkan mekanisme file transfer yang digunakan, serta lingkaran berwarna merah menunjukkan lokasi HTC dipasang/diinstall (pada lingkungan cluster, HTC hanya diinstall pada salah satu node saja yang dijadikan sebagai master node) Pada bagian yang berwarna hijau, menunjukkan fungsi atau peran dari masingmasing kumpulan komputer yang adaPada bagian yang berwarna biru, menunjukkan basis lingkungan komputasi yang digunakan Sebagai tambahan informasi, khusus untuk portal sendiri diinstal pada komputer (host) yang sama dengan head node untuk Pool Cluster untuk meningkatkan efisiensi jumlah komputer yang dibutuhkan untuk penelitian ini. Secara umum, penginstalan portal dapat dilakukan mana saja, dengan syarat bahwa portal tidak diinstal pada mesin HPC. Portal dapat diinstal pada komputer (host) yang sama dengan head node atau pada komputer (host) yang terpisah dan berbeda.Secara lebih mendetil perihal masing-masing host komputer yangdigunakan:

Tabel 1 Penjelasan Host Komputer tahap pertama yang digunakan (Kamah, 2017)

\begin{tabular}{|l|l|l|l|l|}
\hline Peran & Pool & Alamat IP & $\begin{array}{l}\text { Terdap } \\
\text { at } \\
\text { HTC ? }\end{array}$ & $\begin{array}{l}\text { Aplikasi yang } \\
\text { terinstal }\end{array}$ \\
\hline $\begin{array}{l}\text { Condor } \\
\text { Portal }\end{array}$ & & $\begin{array}{l}152.118 .31 \\
41\end{array}$ & Tidak & XAMPP Server \\
\hline Head Node & Cluster & $\begin{array}{l}152.118 .31 . \\
\text { Xa }\end{array}$ & Ya & mpich2, Gromacs \\
berbasis MPI
\end{tabular}

\begin{tabular}{|c|c|c|c|c|}
\hline $\begin{array}{l}\text { (Matchmake } \\
\text { Central } \\
\text { Manager, } \\
\text { Scheduler) }\end{array}$ & GPU & $\begin{array}{l}152.118 .31 . \\
29\end{array}$ & Ya & $\begin{array}{l}\text { CUDA, Gromacs } \\
\text { berbasis GPU }\end{array}$ \\
\hline & Cluster & $\begin{array}{l}152.118 .31 . \\
52\end{array}$ & Ya & $\begin{array}{l}\text { mpich2, Gromacs } \\
\text { berbasis MPI, } \\
\text { Amber berbasis MPI }\end{array}$ \\
\hline $\begin{array}{l}\text { Resources } \\
\text { Node }\end{array}$ & & $\begin{array}{l}152.118 .31 . \\
53\end{array}$ & Tidak & $\begin{array}{l}\text { mpich2, Gromacs } \\
\text { berbasis MPI, } \\
\text { Amber berbasis MPI }\end{array}$ \\
\hline
\end{tabular}




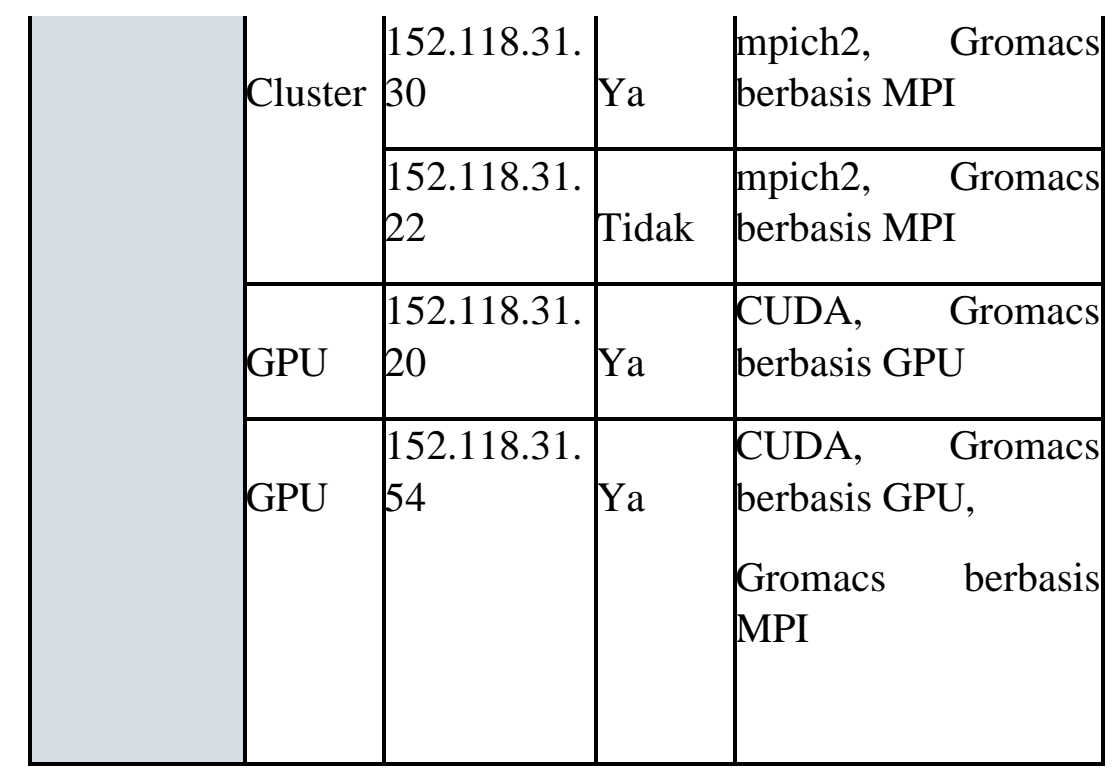

Koneksi antara portal dengan kedua head node dilakukan melalui SSH atau SCP. Sedangkan koneksi maupun mekanisme file transfer antara kedua head node dengan masing-masing resources node di dalam pool masing-masing dengan menggunakan Condor File

Transfer.

Sebagai tambahan informasi, khusus untuk koneksi antara portal dengan head node untuk Pool Cluster adalah berupa koneksi SSH ke komputer yang sama (dikarenakan penggunaan komputer yang sama untuk portal dan head node untuk Pool Cluster).

\section{METODOLOGI DAN PELAKSANAAN}

\subsection{Metodologi}

Berikut ini merupakan tahap-tahap yang dilakukan oleh para peneliti kami untuk mengatasi permasalahan yang dihadapi oleh mitra
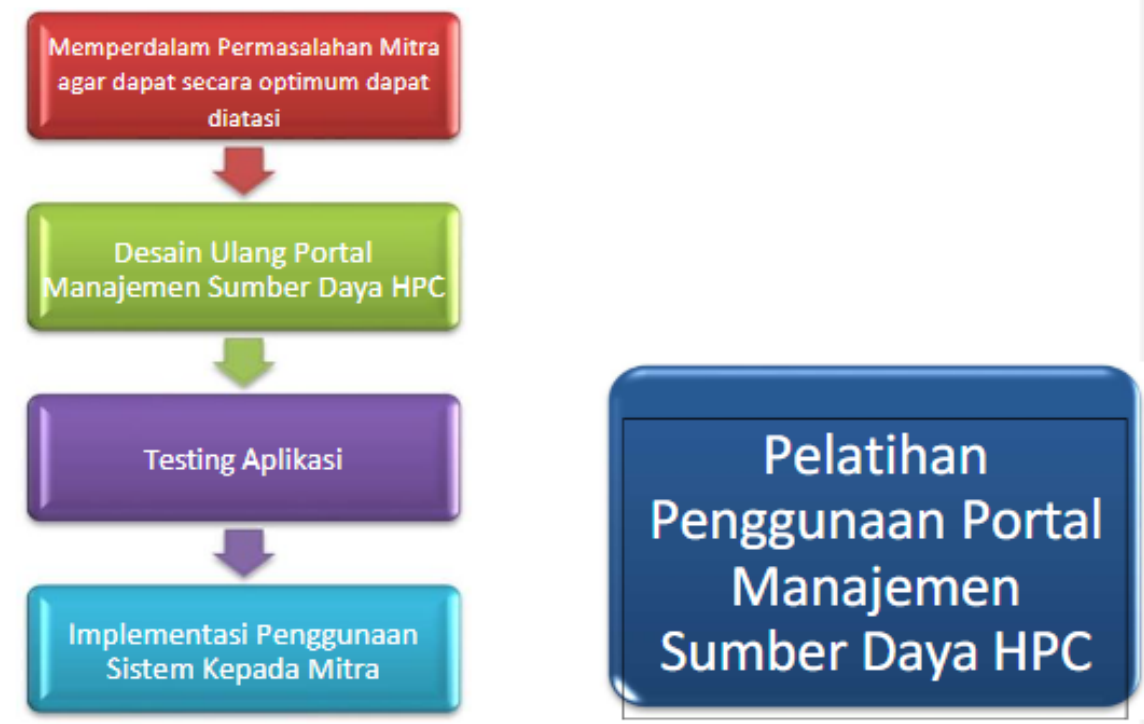

Gambar 2 Pendekatan Metode untuk Penyelesaian Permasalahan 


\section{Memperdalam pendefinisian Permasalahan Mitra}

Pendefinisian permasalahan mitra merupakan salah satu cara untuk mengetahui kebutuhan dari mitra pengelola (Mahasiswa/Peneliti Fakultas Farmasi UI, ITB, UNPAD). Dengan berkomunikasi dan saling sharing pengalaman mengenai cara penyaluran dan business process tahapan-tahapan simulasi dinamika molekular, tim pengembang aplikasi dan pihak mitra dapat berkolaborasi satu sama lain untuk mengembangkan portal manajemen sumber daya HPC.

\section{Desain Ulang Portal Manajemen Sumber Daya HPC}

Tahap pembuatan design portal manajemen sumber daya HPC merupakan tugas dari tim pengembang aplikasi dalam men-design sistem. Tahapan-tahapan update design aplikasi antara lain: update design interface sistem, update design database, dan update alur kerja sistem.

\section{Testing Aplikasi}

Testing aplikasi merupakan tahapan-tahapan percobaan aplikasi pada simulasi dinamika molekuler. Dengan testing aplikasi ini diharapkan tim riset fakultas Ilmu komputer dapat mengetahui performance dan efektifitas dari sistem yang dibuat untuk simulasi dinamika molekuler.

\section{Implementasi Penggunaan Sistem kepada Mitra (Pelatihan)}

Pada tahap ini, portal manajemen sumber daya HPC akan diimplementasikan pada server UI, sehingga setiap mahasiswa dan peneliti mitra tidak perlu memikirkan masalah pengelolaan/perawatan sistem. Diharapkan dengan portal manajemen sumber daya HPC ini, mahasiswa/peneliti mitra dapat lebih produktif dalam melakukan penelitian yang membutuhkan simulasi dinamika molekular.

Jika dituangkan dalam model Input-Proses-Output-Come, maka dapat dirincikan sebagai berikut

1. Input - Mitra: Fakutas Farmasi UI, Program Studi Kimia ITB, Program Studi Farmasi ITB, Program Studi Farmasi UNPAD; Portal Manajemen Sumberdaya HPC yang disiapkan tim pengusul.

2. Proses - memperdalam permasalahan mitra, persiapan portal sumber daya HPC, testing dan pelatihan pemakaian portal pada mitra.

3. Output - alat ukur berupa kuesionair yang telah terisi Outcome - mitra dapat menggunakan portal dengan baik sebagai peneliti, hal ini dapat dilihat dari peningkatan skore penguasaan pemakain portal dari sangat sulit pemakaiannya dan sangat tidak nyaman menjadi meningkat minimal cukup mudah dan cukup nyaman menggunakan portal dan melakukan eksperimen serta memberikan asupan apa saja yang perlu diperbaiki pada portal tersebut. 


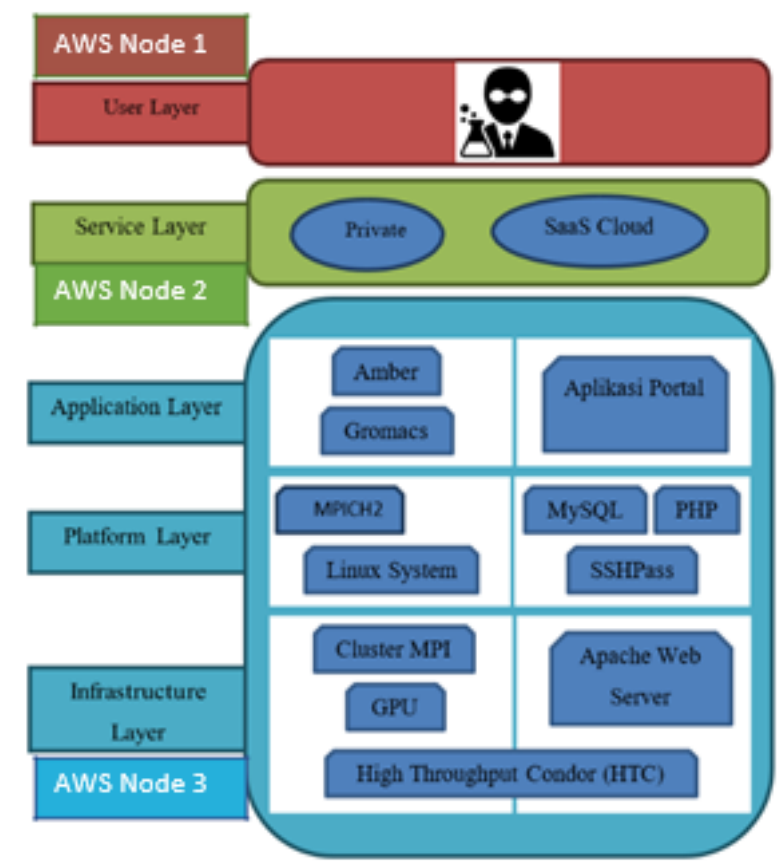

Gambar 3 Gambāản ümum sistem yang diajükañ (Kamäh, 2017)

Pada gambar 3, disajikan gambaran umum system yang diajukan sebelumnya (Kamah, 2017). Dalam implementasi, system ini dapat dipasang pada suatu node yang mempunyai koneksi dengan sumber daya komputasi. Saat eksperimen awal, node dan sumber daya komputasinya ada jaringan UI. Namun saat ujicoba ini, kami menyewa node di AWS dan memasangnya di sana. Sedangkan sumber daya komputasinya, kami sewa dua jenis yakni Cluster dan GPU yang ada di AWS juga. Pemasangan system di luar UI mempertimbangkan kemudahan akses sumber daya di luar UI Pada Gambar .3 AWS dipakai untuk sebagai penyedia infrastruktur yang digunakan.

Gambar.3 merupakan design infrastruktur sistem HPC yang kami usulkan. Design tersebut generic dan dapat digunakan pada platform lain AWS. Design tersebut sangat memungkinkan untuk diimplementasi ke dalam bare metal machine atau infrastruktur cloud lainya.

\subsection{PELAKSANAAN}

Mengingat pengaturan yang cukup ketat dalam mengakses sumber daya komputasi di lingkungan UI, maka untuk memperlancar ujicoba koneksi dengan berbagai sumber daya komputasi di luar UI dan mengurangi kendala aturan akses jaringan di lungkungan UI, maka kami melakukan berbagai perbaikan pada portal dan memasangnya di Amazon Web Service. Saat ujicoba, Portal dipasang di alamat sementara http://cloud.herbaldb.info/ dan hanya berfungsi beberapa minggu. Untuk implementasi permanent, akan dipakai alamat yang lain Sumber daya komputasi yang kami pilih adalah

dua pool system Cluster dan dua pool system GPU. Dua jenis user kami definisikan yakni administrator yang dapat mengkonfigurasi portal dan users, dan 
user pemakai yang diperuntukkan bagi akademisi atau pemakai yang siap melakukan eksperimen dengan memasukkan data pilihannya sendiri. Rincian desain dan implementasi prototype, perbaikan, pemasangan, cara memakai dan ujicoba portal disajikan secara rinci pada (Kamah et.al, 2019). Berikut adalah penampakan beberapa jendela user administrator saat mengelola portal di Amazon Web Service (AWS).

Pelaksaaan sosialiasi dan diskusi dengan mitra yakni UNPAD dan ITB di lakukan pada hari Senin tanggal 18 November 2019. Pelaksanaan

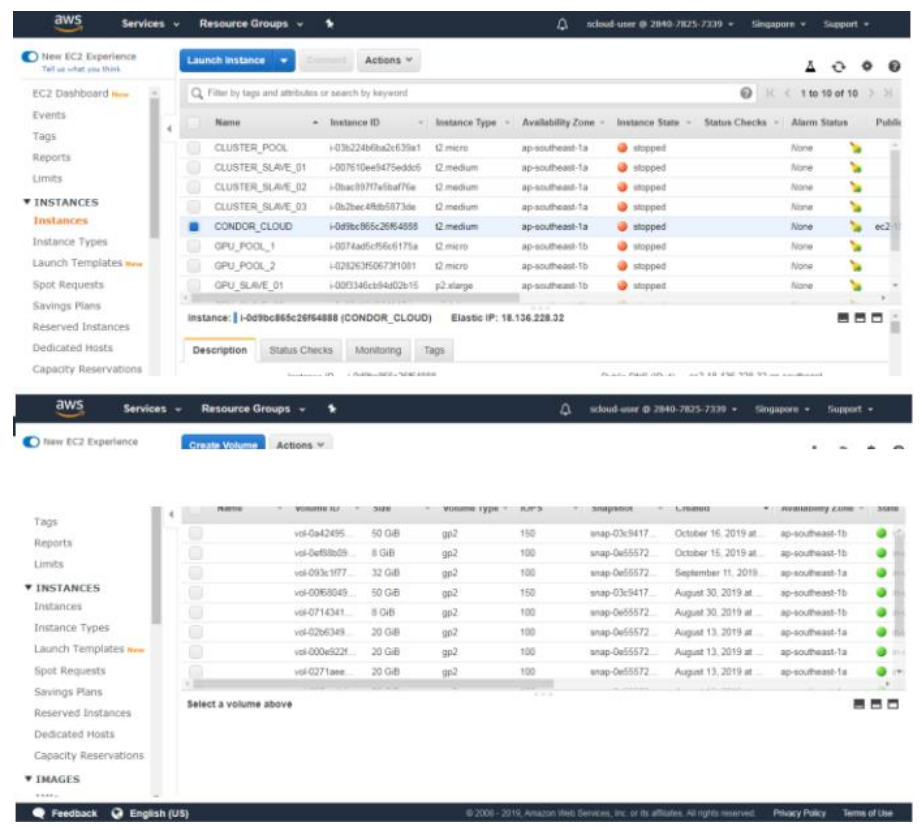

Gambar 4 Pengelolaan sumber daya komputasi di AWS

pertama dilakukan di UNPAD dari pukul 9.00 WIB sampai dengan pukul Gambar 5 Pengelolaan penyimpanan data di AWS

11.00 dilanjutan di ITB pada pukul 13.00 sampai dengan pukul 15.00. Dalam satu jam pertama sosilisasi dilakukan presentasi tiga materi utama, yakni selanjutnya dilanjutkan dengan tanya jawab dan ujicoba oleh beberapa peserta. Berikut adalah penampakan gambar saat kegiatan sosialisasi

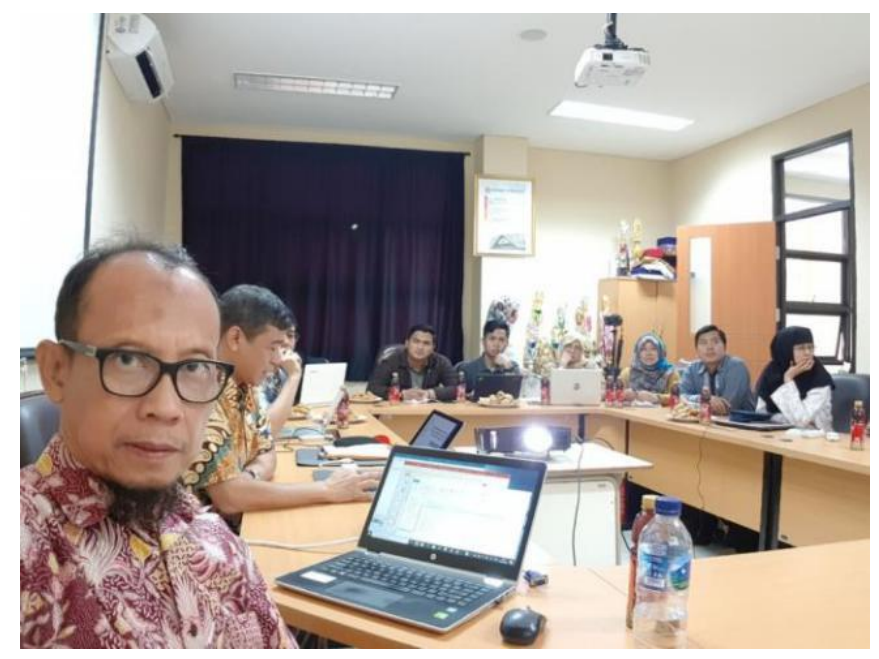


Gambar 6 Kegiatan sosialisasi di UNPAD

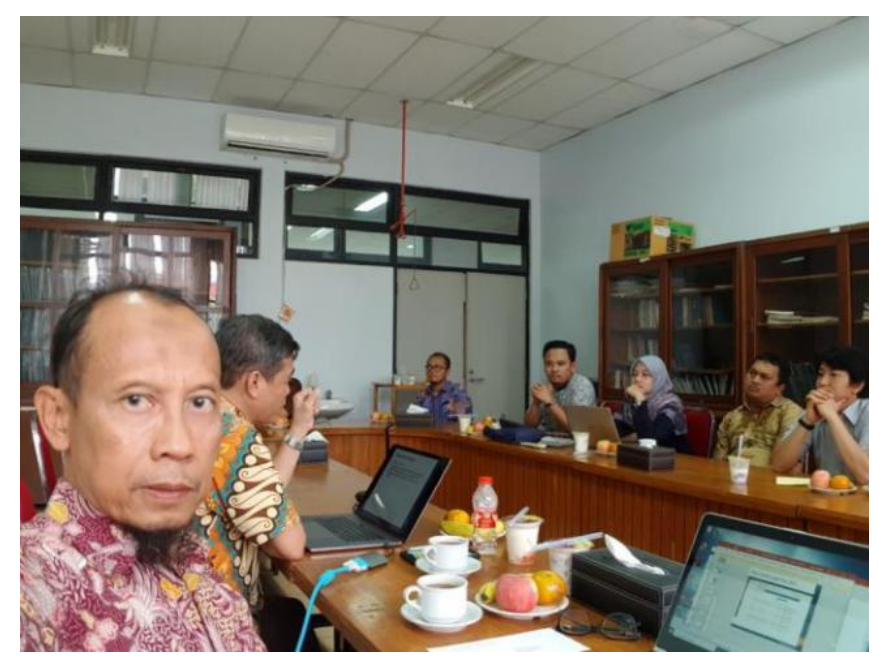

Gambar 7 Kegiatan sosialisasi di ITB

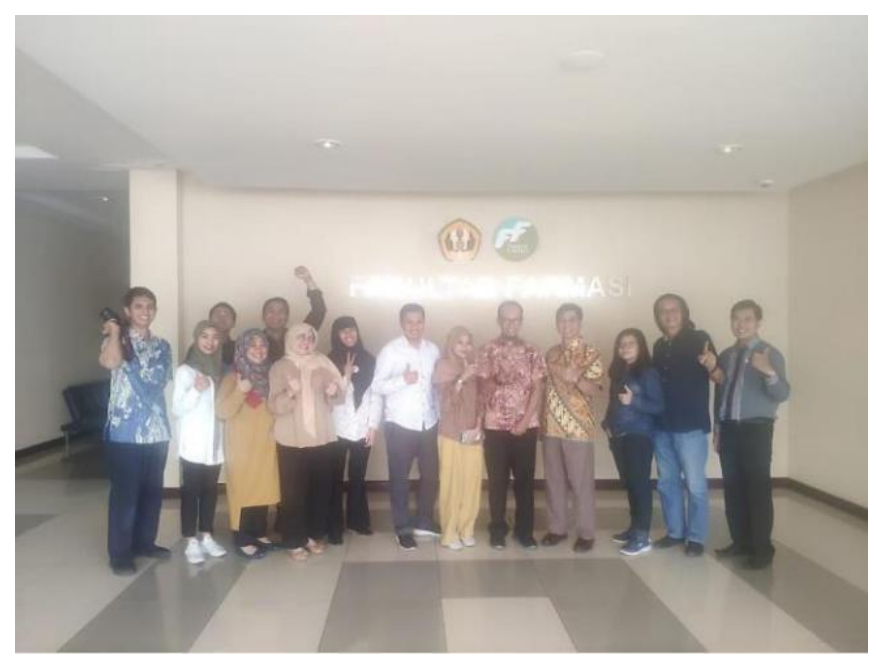

Gambar 8 Peserta sosialisasi di UNPAD 
Tabel 2 Materi presentasi

\begin{tabular}{|c|c|c|}
\hline No & Pembicara & Materi \\
\hline 1 & Prof. Heru & $\begin{array}{l}\text { Implementasi Portal Manajemen } \\
\text { Sumber Daya } \\
\text { HPC dengan Load Balancer dan } \\
\text { Job Scheduler } \\
\text { berbasiskan High Throughput } \\
\text { Condor }\end{array}$ \\
\hline 2 & $\begin{array}{ll}\text { Prof. } & \text { Arry } \\
\text { Yanuar } & \end{array}$ & Tutorial dan workshop (Amber) \\
\hline 3 & $\begin{array}{l}\text { Ari Wibisono, } \\
\text { M.Kom }\end{array}$ & $\begin{array}{l}\text { Tutorial dan workshop } \\
\text { (Gromacs), dan contoh } \\
\text { contoh pemakaian mulai dari } \\
\text { login, hingga } \\
\text { memantau eksperimen di system }\end{array}$ \\
\hline
\end{tabular}

Portal dibuka dan dipakai untuk ujicoba hingga tanggal 30 November 2019, setelah melakukan ujicoba users mitra mengisi kuesioner yang telah disiapkan di situs http://bit.ly/sosialisasi-191118 dan http://bit.ly/kuesioner2-sosialisasi191118. Rekapitulasi pendapat user tersedia pada tabel 3.

Tabel 3 Pendapat peserta tentang kegiatan sosialisasi

\begin{tabular}{|c|c|c|c|c|}
\hline Kriteria & $\begin{array}{l}\text { Tidak } \\
\text { puas }\end{array}$ & $\begin{array}{l}\text { Cukup } \\
\text { Puas }\end{array}$ & Puas & $\begin{array}{l}\text { Sangat } \\
\text { Puas }\end{array}$ \\
\hline $\begin{array}{l}\text { Kegiatan } \\
\text { dapat } \\
\text { memperbaiki } \\
\text { kami } \\
\text { sebelumnya }\end{array}$ & & & & $100 \%$ \\
\hline $\begin{array}{l}\text { Program mampu } \\
\text { mengangkat } \\
\text { potensi lokal daerah } \\
\text { kami }\end{array}$ & & & $80 \%$ & $20 \%$ \\
\hline
\end{tabular}


Charity Jurnal Pengabdian Masyarakat Vol.03 No.02 (2020)

\begin{tabular}{|c|c|c|c|}
\hline $\begin{array}{l}\text { Program sesuai dengan } \\
\text { harapan } \\
\text { kami }\end{array}$ & $20 \%$ & $40 \%$ & $40 \%$ \\
\hline $\begin{array}{l}\text { Kami dapat melanjutkan } \\
\text { program } \\
\text { tanpa adanya bantuan/ } \\
\text { pendampingan dari tim } \\
\text { UI }\end{array}$ & $20 \%$ & $80 \%$ & \\
\hline $\begin{array}{l}\text { Program bisa membuat } \\
\text { kami } \\
\text { mandiri }\end{array}$ & $40 \%$ & $60 \%$ & \\
\hline
\end{tabular}

\begin{tabular}{|c|c|c|c|}
\hline 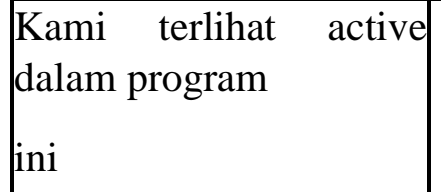 & $20 \%$ & $80 \%$ & \\
\hline $\begin{array}{l}\text { Program menjunjung } \\
\text { tinggi } \\
\text { penghormatan terhadap } \\
\text { adat } \\
\text { istiadat dan nilai nilai } \\
\text { masyarakat }\end{array}$ & & & $100 \%$ \\
\hline $\begin{array}{l}\text { Tim UI berperilaku } \\
\text { sopan santun, } \\
\text { baik dan jujur }\end{array}$ & & $80 \%$ & $20 \%$ \\
\hline
\end{tabular}




\section{KESIMPULAN DAN OUTCOME}

Peserta acara diskusi dan sosialisasi seluruhnya berlatar belakang pendidikan sarjana/pascasarjana dan hampir dari separuh berprofesi sebagai dosen/peneliti.

Berdasarkan hasil kuesioner table 3, seluruh peserta merasa puas dengan kegiatan sosialisasi ini dan menganggapnya dapat membantu memperbaiki kondisi mereka. Sistem yang diperkenalkan ini juga dianggap sesuai oleh seluruh peserta untuk mengangkat potensi bidang mereka (farmasi/kimia). Sebagian besar peserta juga merasa puas dengan acara yang diselenggarakan ini dan merasa cukup mampu untuk memanfaatkan sistem ini secara mandiri tanpa bantuan/pendampingan dari tim UI.

Sistem yang telah dikembangkan dianggap sebagai sesuatu yang baru bagi peserta dan menambah wawasan mereka. Dengan sistem ini peserta merasa dapat melakukan eksperimen dengan sumber daya komputasi yang diinginkan secara lebih mudah dengan memanfaatkan teknologi cloud computing. Harapan dari peserta adalah adanya penambahan fitur untuk preparasi data input, serta visualisasi hasil/output eksperimen. Sebagian peserta juga menyarankan dibuatnya panduan yang lebih lengkap untuk pemula dan disediakannya layanan bantuan dari tim UI.

Secara keseluruhan, sebagian peserta merasa sudah dilibatkan secara aktif dalam kegiatan diskusi dan sosialisasi ini. Seluruh peserta mengganggap acara ini menjunjung tinggi nilai-nilai adat istiadat dan nilai-nilai masyarakat setempat dan diselenggarakan secara sopan, santun, baik, serta jujur oleh tim UI. 


\section{DAFTAR PUSTAKA}

(Wibisono and Suhartanto, 2012) A. Wibisono and H. Suhartanto, "Cloud Computing Model and Implementation of Molecular Dynamics Simulation using Amber and Gromacs," in Icacsis, 2012,978-979., https://ieeexplore.ieee.org/document/6468763

(Abdelbaky, et. al, 2012) M. Abdelbaky, M. Parashar, H. Kim, K. E. Jordan, V. Sachdeva, J.Sexton, H. Jamjoom, Z. Y. Shae, G. Pencheva, R. Tavakoli, and M. F. Wheeler, "Enabling high-performance computing as a service," Computer (Long. Beach. Calif)., vol. 45, no. 10, pp. 72- 80, 2012.

(Jorissen et al., 2012) K. Jorissen, F. D. Vila, and J. J. Rehr, "A high performance scientific cloud computing environment for materials simulations," Comput. Phys. Commun., vol. 183, no. 9,1911-1919, 2012.(Chen et. al., 2012) Z. Chen, N. Chen, C. Yang, and L. Di, "Cloud computing enabled web processing service for earth observation data processing," IEEE J. Sel. Top. Appl. Earth Obs.Remote Sens., vol. 5, no. 6, pp. 1637-1649, 2012.

(Ambermd, 2015) Ambermd, "The Amber Molecular Dynamics Package," ambermd.org, 2015. [Online]. Available: http://ambermd.org/. [Accessed: 18-Jun2015].

(Gromacs, 2015), “Gromacs," 2015. [Online]. Available: http://www.gromacs.org/. [Accessed: 18-Jun-2015].

(Ratsanjani, 2016) Ratsanjani, M. Hasyim. (2016). Pengembangan SAAS Cloud Untuk Menjalankan Aplikasi Simulasi Dinamika Molekular Dengan Kemampuan Integrasi Lingkungan Komputasi HPC. Master Thesis. Depok: Universitas Indonesia.

(Holl et. al., 2014) S. Holl, O. Zimmermann, M. Palmblad, Y. Mohammed, and M. Hofmann-Apitius, "A new optimization phase for scientific workflow management systems,” Futur.Gener. Comput. Syst., vol. 36, pp. 352-362, 2014.

(Kamah, 2017) Kamah, D. Pratama. (2017). Implementasi Portal Manajemen Sumber Daya HPC dengan Load Balancer dan Job Scheduler berbasiskan High Throughput Condor. Skripsi. Depok: Universitas Indonesia.

(Kamah et al., 2018) Kamah, D. Pratama, Ari Wibisono, and Heru Suhartanto (2018), Implementation of HPC Resource Management Portal with Load Balancer and Job Scheduler based on High Throughput Condor, PRAGMA 34 Workshop, Akihabara, Tokyo, Japan, 2018, grid.net/images/pragma34/Kammah.pdf

(Kamah et al. 2019), Kamah, D. Pratama, Ari Wibisono, Yohanes Gultom, Arry Yanuar, Heru Suhartanto, Implementasi Portal Manajemen Sumder Daya HPC Simulasi Dinamika Molekuler, dalam persiapan cetak., 2019 
(Rajan et all, 2011) D. Rajan, A. Canino, J. a. Izaguirre, and D. Thain, "Converting a high-performance application to an elastic cloud application," Proc. - 2011 3rd IEEE Int. Conf. Cloud Comput. Technol. Sci. CloudCom 2011, pp. 383-390, 2011.(Wong and Goscinki, 2013) A. K. L. Wong and A. M. Goscinski, "A unified framework for the deployment, exposure and access of HPC applications as services in clouds," Futur. Gener. Comput. Syst., vol. 29, no. 6, pp. 1333-1344, 2011 